\title{
PEMANFAATAN EKSTRAK BIJI CERAKIN (Croton tiglium L) SEBAGAI INSEKTISIDA NABATI TERHADAP ULAT DAUN BAWANG (Spodoptera exigua Hubn)
}

\author{
Utilization of Extract of Cerakin Seeds (Croton tiglium L) as Natural \\ Insecticides on Caterpillar Leek (Spodoptera exigua Hubn)
}

\author{
*Nif'atul Jannah, Ratman, dan Irwan Said \\ Pendidikan Kimia/FKIP - Universitas Tadulako, Palu - Indonesia 94118 \\ Received 09 December 2015, Revised 11 January 2016, Accepted 08 February 2016
}

\begin{abstract}
The research aim is to determine the ability of cerakin seeds as natural insecticide on caterpillar leek (Spodoptera exigua Hubn). In this study, the cerakin seeds from Saloya village, Labuan Panimba village Donggala, and Sidole Village Ampibabo, Central Sulawesi are used as sample. The extraction of cerakin seeds was extracted by using ethanol and then were tested on caterpillar leek (Spodoptera exigua) with a concentration of extract 15\%, 25\%, 35\%, 45\% and 55\%. The results showed that for each concentration gives vary results in killing larvae of caterpillar leek (Spodoptera exigua), the higher concentration gives the more mortality of caterpillar leek's larvae (Spodoptera exigua). Therefore it can be said that the extract of cerakin seeds can be used as an natural insecticide on caterpillar leek (Spodoptera exigua) and is also able to kill the larvae caterpillar leek (Spodoptera exigua) 93.3\% to $100 \%$.
\end{abstract}

Keywords: Insecticides vegetable, cerakin (Croton tiglium), spodoptera exigua

\section{Pendahuluan}

Indonesia merupakan negara yang dilalui garis khatulistiwa sehingga beriklim tropis. Hal ini menjadikan negara Indonesia sangat subur hingga memungkinkan berbagai jenis tumbuhan yang hidup dan berkembang dengan subur. Banyak diantara tanaman ini memiliki manfaat yang besar bagi kehidupan manusia baik sebagai obat tradisional, bahan rempah, pewarna alami maupun sebagai pestisida nabati. Namun tidak sedikit dari jenis tanaman tersebut belum dikenal dan diketahui manfaatnya secara luas.

Salah satu dari jenis tanaman yang memiliki banyak manfaat namun belum dikenal secara luas yaitu tanaman cerakin. Berdasarkan kriteria IUCNNR (International Union for the Conservation of Nature and Natural Resources), status tanaman cerakin termasuk kategori terkikis (indeterminate), karena sedang mengalami kelangkaan. Statusnya ada atau

\section{*Correspondence:}

Nif'atul Jannah

Program Studi Pendidikan Kimia, Fakultas Keguruan dan

Ilmu Pendidikan, Universitas Tadulako

email: jannahnifatul293@gmail.com

Published by Universitas Tadulako 2016 tersedia namun dalam jumlah terbatas dengan sebaran tidak menentu dan kurang terpantau, karena kurang perhatian (Ahmadi dkk., 2011).

Tanaman ini menyebar ke berbagai daerah di Indonesia, dengan nama yang berbedabeda antara lain simalakian (Sumatera Barat), ceraken (Jawa), roengkok (Sumatera Utara), semoeki (Ternate), kowe (Tidore), kamandrah (Kalimantan), kemalakian (Sunda), kamalakian (Sunda), cempala (Bugis), kelmure (Halmahera Selatan), tupo (Halmahera Utara), semuli (Ternate), dan ceraken atau cerakin (Indonesia) (Ahmadi dkk., 2011).

Selain terdapat di daerah-daerah tersebut, tanaman ini juga ditemukan di beberapa wilayah di Sulawesi Tengah, yang disebut dengan nama kamande. Di Sulawesi Tengah sendiri tanaman ini juga dimanfaatkan oleh sebagian masyarakat sebagai racun ikan, dan ada juga yang memanfaatkannya sebagai insektisida. Namun banyak masyarakat Sulawesi Tengah belum mengetahui tanaman ini. Selain itu tanaman ini hampir tak ditemukan lagi.

Hasil utama tanaman ini adalah biji yang mengandung minyak sebesar $25-26 \%$ dan 
mengandung senyawa piperin (Iswantini dkk., 2007). Senyawa golongan piperine dan piperidine dapat digunakan sebagai insektisida. Manfaat lain dari biji cerakin adalah sebagai racun ikan, obat laksatif, dan obat nyamuk atau pembunuh jentik (Saputera dkk., 2008). Uraian di atas terdapat begitu banyak manfaat dari tanaman cerakin salah satunya yaitu sebagai insektisida. Hal tersebut menarik peneliti untuk melakukan penelitian mengenai pemanfaatan biji cerakin sebagai insektisida nabati terhadap ulat daun bawang (Spodoptera exigua).

Tulisan ini dimaksudkan untuk menentukan kemampuan ekstrak biji cerakin sebagai insektisida nabati terhadap ulat daun bawang (Spodoptera exigua).

\section{Metode}

Sampel yang digunakan pada penelitian ini adalah biji cerakin yang diperoleh dari Desa Saloya, Desa Labuan Panimba Kabupaten Donggala, dan Desa Sidole kecamatan Ampibabo, Sulawesi Tengah. Alat yang digunakan dalam penelitian ini yaitu evaporator, blender, aspirator, neraca digital, gelas kimia, labu erlenmeyer, gelas ukur, batang pengaduk, penyaring maserasi, wadah (sebagai tempat hama). Bahan yang digunakan dalam penelitian ini yaitu biji cerakin, etanol (aethanolum 70\%), kertas saring, kertas label, kain kasa, tissue, karet gelang, aquades, dan ulat daun bawang (Spodoptera exigua).

Penelitian ini dilakukan dengan menggunakan rancangan acak lengkap yang terdiri dari 6 perlakuan yang diulang sebanyak 3 kali. Perlakuan terdiri dari kontrol air (P0), konsentrasi ekstrak cerakin 15\% (P1), konsentrasi ekstrak cerakin 25\% (P2), konsentrasi ekstrak cerakin 35\% (P3), konsentrasi ekstrak cerakin 45\% (P4), dan konsentrasi ekstrak cerakin 55\% (P5).

\section{Prosedur Kerja}

Langkah pertama yang dilakukan biji cerakin dirajang kecil-kecil dan dikeringkan dengan cara diangin-anginkan, kemudian diblender. Sebanyak 250 gram sampel yang telah dihaluskan diekstrasi dengan cara maserasi yakni sampel direndam dalam pelarut etanol pada tabung atau toples selama 2 hari atau 48 jam secara bertahap. Setelah itu ekstrak disaring, lalu filtrat yang diperoleh dimasukkan ke dalam alat evaporator. Ekstrak cerakin diencerkan dengan etanol menjadi beberapa konsentrasi yaitu 15\%, 25\%, 35\%, 45\%, dan 55\%. Ekstrak biji cerakin disemprotkan pada hama ulat daun bawang yang tersedia dalam tiap wadah (10 ekor tiap wadah) untuk masing-masing konsentrasi dan dilakukan 3 kali ulangan, selajutnya jumlah ulat daun bawang (Spodoptera exigua) yang mati diamati pada setiap perlakuan pada masing-masing konsentrasi dengan interval pengamatan dilakukan setiap 6 jam.

\section{Hasil dan Pembahasan}

Hasil pengamatan kematian ulat daun bawang pada pengujian berbagai konsentrasi ekstrak cerakin ditampilkan dalam Tabel 1 dan Gambar 1

Tabel 1. Rata-rata mortalitas ulat daun bawang (Spodoptera exigua) pada pengujian berbagai konsentrasi ekstrak cerakin di Laboratorium 6 jam s/d 108 jam setelah aplikasi (JSA)

\begin{tabular}{|c|c|c|c|c|c|c|c|c|c|c|c|c|c|c|c|c|c|c|}
\hline \multirow[t]{2}{*}{ Perlakuan } & \multicolumn{18}{|c|}{ Jam Setelah Aplikasi (JSA) (10 ekor Larva/ Unit Ulangan) } \\
\hline & 6 & 12 & 18 & 24 & 30 & 36 & 42 & 48 & 54 & 60 & 66 & 72 & 78 & 84 & 90 & 96 & 102 & 108 \\
\hline Po (kontrol) & $0 \mathrm{a}$ & $0,33 \mathrm{a}$ & $0,33 \mathrm{a}$ & $0,33 \mathrm{a}$ & $0,33 \mathrm{a}$ & $0,33 \mathrm{a}$ & $0,33 \mathrm{a}$ & $0,33 \mathrm{a}$ & $0,33 \mathrm{a}$ & $0,33 \mathrm{a}$ & $0,33 \mathrm{a}$ & $0,33 \mathrm{a}$ & $0,33 \mathrm{a}$ & $0,33 \mathrm{a}$ & $0,33 \mathrm{a}$ & $0,33 \mathrm{a}$ & $0,33 \mathrm{a}$ & $0,33 \mathrm{a}$ \\
\hline $\mathrm{P} 1(15 \%)$ & $2 a b$ & 3,36 & 3,76 & $4,7 \mathrm{~b}$ & $5 b$ & $5,3 b$ & $5,7 \mathrm{~b}$ & $5,7 b$ & $5,7 \mathrm{~b}$ & $6 \mathrm{~b}$ & $7,3 \mathrm{~b}$ & $7,7 \mathrm{~b}$ & 86 & $8,3 b$ & 8,76 & $9 b$ & $9 b$ & 9,36 \\
\hline $\mathrm{P} 2(25 \%)$ & $5 \mathrm{de}$ & $5 \mathrm{ed}$ & $5,3 \mathrm{~cd}$ & ocd & $7 \mathrm{~cd}$ & $7 \mathrm{~cd}$ & $7 c$ & $7,3 \mathrm{c}$ & $7,7 \mathrm{c}$ & $7,7 \mathrm{c}$ & $8 b c$ & $8 b c$ & $8,3 b c$ & $8,7 b c$ & 8,76 & 9,36 & 9,36 & $10 \mathrm{c}$ \\
\hline P3 $(35 \%)$ & $2,7 b c$ & $4 b c$ & $5,3 \mathrm{~cd}$ & ocd & $6,3 b c$ & $7 \mathrm{~cd}$ & $7,7 \mathrm{~cd}$ & $7,7 \mathrm{~cd}$ & $8 \mathrm{~cd}$ & $8,3 \mathrm{~cd}$ & $8,7 \mathrm{~cd}$ & 9cde & $9 b c d$ & $9 b c$ & $9 b$ & $9,3 \mathrm{~b}$ & 9,36 & $10 \mathrm{c}$ \\
\hline P4 (45\%) & $3,7 \mathrm{bcd}$ & $4,7 b c d$ & $6,7 d$ & $7,3 \mathrm{~d}$ & $7,3 \mathrm{~cd}$ & scd & 8,7de & $8,7 \mathrm{cde}$ & $8,7 \mathrm{cde}$ & $8,7 \mathrm{cde}$ & $8,7 \mathrm{~cd}$ & 9de & 9bcd & $9,3 \mathrm{bc}$ & $9,3 b$ & $9,3 \mathrm{~b}$ & $9,3 b$ & $10 \mathrm{c}$ \\
\hline P5 (55\%) & $7,7 \mathrm{e}$ & $8,7 \mathrm{e}$ & $9,3 \mathrm{e}$ & $9,7 \mathrm{e}$ & $9,7 \mathrm{e}$ & $9,7 \mathrm{e}$ & $9,7 \mathrm{e}$ & $9,7 \mathrm{e}$ & $9,7 \mathrm{e}$ & $9,7 \mathrm{e}$ & $9,7 \mathrm{~d}$ & $9,7 \mathrm{e}$ & $9,7 \mathrm{de}$ & $9,7 \mathrm{c}$ & 9,76 & 9,76 & 9,76 & $10 \mathrm{c}$ \\
\hline BNJ 0,05\% & 2,24 & 1,49 & 1,71 & 1,48 & 1,42 & 1,29 & 1,05 & 1,29 & 1,39 & 1,39 & 1,29 & 1,29 & 1,29 & 1,24 & 1,05 & 0,82 & 0,82 & 0,52 \\
\hline
\end{tabular}

Ket : Angka rata-rata yang diikuti huruf yang sama pada kolom yang sama tidak berbeda nyata pada taraf uji BNJ 5\% $(0,05)$ 


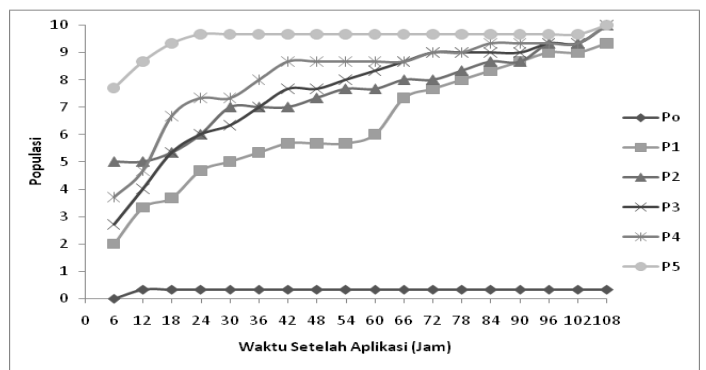

Gambar 1. Rata-rata mortalitas larva ulat daun bawang (Spodoptera exigua) pada Pengujian berbagai konsentrasi estrak cerakin. di Laboratorium 6 jam setelah aplikasi s/d 108 jam setelah aplikasi

Berdasarkan Tabel 1 dan Gambar 1 menunjukkan bahwa pemberian ekstrak biji cerakin dengan konsentrasi berbeda memberikan pengaruh berbeda pula terhadap tingkat kematian ulat daun bawang. Hal ini mengindikasikan bahwa ekstrak biji cerakin memiliki sifat insektisida yang bekerja secara perlahan. Senyawa aktif dari ekstrak biji cerakin antara lain Piperine dan Senyawa 1,4-naphthoquinone. Pada pengamatan 6 JSA dan 12 JSA telah terlihat adanya ulat daun bawang yang mati baik pada perlakuan P1, P2, P3, P4 maupun P5, namun pada perlakuan P2 jumlah ulat daun bawang yang mati lebih tinggi bila dibandingkan dengan perlakuan $\mathrm{P} 3$ dan P4. Kematian hewan uji meningkat secara perlahan-lahan pada pengamatan selanjutnya hingga pengamatan 108 JSA. Dari beberapa kali pengamatan ditemukan jumlah hewan uji yang mati cenderung sama yakni pada perlakuan P1 dan P2 pada 90 JSA; P2 dan P3 pada pengamatan 18 JSA, 24 JSA ,36 JSA, serta P4 dan P3 pada 66 JSA. Menurut Makal \& Defly (2011), bahwa hal tersebut berkaitan dengan keragaman ginetik dari setiap individu (larva) dalam suatu populasi. Sesuai dengan Corbet dkk. (1984), menyatakan bahwa setiap individu dalam suatu populasi berbeda kecepatan dan cara untuk menetralisir racun yang termakan. Sejalan dengan hal tersebut Ardiansyah dkk. (2002) juga menyatakan bahwa meningkatnya angka mortalitas anakan dapat disebabkan karena kondisi masingmasing larva kurang seragam dalam merespon efek toksik esktrak, sehingga penyerapan yang terjadi secara perlahan-lahan akan menyebabkan detoksifikasi.

Selanjutnya pada pengamatan 108 JSA terlihat pada perlakuan P2, P3, P4, dan P5 bahwa kematian larva Spodoptera exigua mencapai $100 \%$ sedangkan pada perlakuan P1 kematian larva mencapai 28 ekor atau 93,3\% dan pupa yang terbentuk sebanyak 2 pupa (6,7\%). Dan pada perlakuan P0 kematian larva sebesar 1 ekor $(3,33 \%)$ dan pupa yang terbentuk sebanyak 29 pupa $(96,7 \%)$. Sebagaimana ditunjukkan pada Tabel 2 dan Gambar 2.

Tabel 2. Hasil pengamatan jumlah larva yang berhasil menjadi Pupa pada 108 jam setelah aplikasi pada setiap perlakuan

\begin{tabular}{ccc}
\hline Perlakuan & Jumlah Larva jadi Pupa & Presentase (\%) \\
\hline Po & 29 & 96 \\
P1 & 2 & 6,67 \\
P2 & 0 & 0 \\
P3 & 0 & 0 \\
P4 & 0 & 0 \\
P5 & 0 & 0 \\
\hline
\end{tabular}

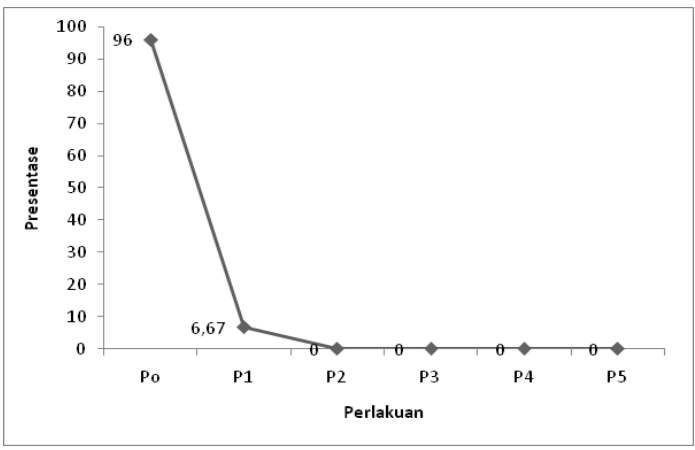

Gambar 2. Jumlah larva ulat daun bawang (Spodoptera exigua) yang berhasil menjadi Pupa pada 108 jam setelah aplikasi pada setiap perlakuan

Data persentase mortalitas larva menandakan bahwa ekstrak biji cerakin dapat digunakan sebagai insektisida botanis untuk mengendalikan larva Spodoptera exigua. Dikatakan demikian karena pada perlakuan P2, P3, P4 dan P5 telah mampu membunuh larva Spodoptera exigua hingga 100\% dari total populasi larva uji. Prijono (1994), mengemukakan bahwa suatu ekstrak dikatakan efektif bila perlakuan dengan ekstrak tersebut dapat mengakibatkan tingkat kematian $>90 \%$.

Pengamatan perilaku serangga uji diketahui larva Spodoptera exigua yang telah terkontaminasi oleh ekstrak biji cerakin terlihat bahwa menurunnya aktifitas makan, kurang agresif, warnanya berubah menjadi hijau pucat, dan lama-kelamaan warnanya berubah menjadi hitam. Sesuai dengan Thamrin dkk. (2007) 
gejala keracunan ditandai dengan menurunnya aktivitas makan dan gerakannya melemah yang mengakibatkan kematian larva. Selain dapat mengganggu aktivitas makan racun yang terkandung dalam ekstrak biji cerakin juga dapat terserap melalui dinding tubuh, dalam hal ini ekstrak biji cerakin berfungsi sebagai racun kontak. Menurut Lu (1995), kulit umumnya impermeabel dan merupakan batas yang memisahkan organisme dari lingkungannya. Zat-zat kimia yang terserap melalui kulit biasanya dalam jumlah besar sehingga akan menimbulkan efek sistemik.

Organisme berukuran kecil umumnya memiliki nisbah antara permukaan badan dengan berat badan relatif besar, sehingga apabila terjadi kontak antara permukaan badan dengan suatu zat, maka senyawa aktifnya dapat dengan mudah terserap. Organisme yang berukuran lebih besar, pada umur yang relatif sama, seringkali lebih tahan terhadap senyawa bioaktif dari pada organisme yang lebih kecil. Perbedaan kepekaan ini berkaitan dengan perbedaan luas permukaan jaringan sasaran, karena kerja suatu racun seringkali melibatkan permukaan jaringan. Pada organisme kecil, senyawa aktif dapat lebih cepat mencapai bagian sasaran dalam konsentrasi yang cukup untuk menimbulkan keracunan dibandingkan organisme yang lebih besar. Organisme muda umumnya lebih peka terhadap aktivitas toksik zat kimia (Koeman, 1987).

Gambar 1 juga menunjukkan adanya larva Spodoptera exigua yang mati pada perlakuan P0 (kontrol) namun matinya larva tersebut hanya terjadi pada pengamatan kedua. Hal tersebut dipengaruhi oleh faktor lingkungan, selain itu juga dapat dipengaruhi oleh perlakuan pada saat persiapan atau bahkan pada saat penelitian berlangsung. Makal \& Defly (2011) mengatakan bahwa serangga akan terhambat pertumbuhan dan perkembangannya atau mati apabila faktor lingkungan tempat hidupnya tidak mendukung baik dari faktor fisis atau dari faktor makanan.

Sebagaimana diketahui bahwa biji cerakin mengandung senyawa kimia seperti saponin, terpenoid dan alkaloid. Pertahanan tumbuhan merupakan metabolik sekunder yang dihasilkan pada jaringan tumbuhan, dan dapat bersifat toksik menurunkan kemampuan serangga dalam mencerna makanan dan pada akhirnya mengganggu pertumbuhan serangga (Siregar $\&$ Etti, 2005). Menurut Rosyidah (2007) bahwa senyawa saponin dapat menimbulkan kelayuan pada saraf serta kerusakan pada spirakel yang mengakibatkan serangga tidak bisa bernafas dan akhirnya mati. Saponin bersifat sebagai racun dan antifeedant pada kutu, larva, kumbang dan berbagai serangga lain.

Senyawa kimia pertahanan tumbuhan merupakan metabolik sekunder atau aleleokimia yang dihasilkan pada jaringan tumbuhan, dan dapat bersifat toksit, menurunkan kemampuan serangga dalam mencerna makanan dan pada akhirnya mengganggu pertumbuhan serangga. Senyawa kimia pertahanan tumbuhan meliputi saponin, terpenoid dan alkaloid (Siregar \& Etti, 2005). Berdasarkan penelitian yang dilakukan oleh Iswantini dkk. (2007) diketahui bahwa senyawa aktif yang berfungsi sebagai insektisida dari ekstrak biji cerakin adalah senyawa piperine. Piperine adalah suatu alkaloida piperidine yang bersifat toksik yang biasa digunakan sebagai insektisida. Selain piperin, Senyawa 1,4-naphthoquinone juga diketahui sebagai insektisida. Menurut Babula dkk. (2007) Senyawa 1,4-naphthoquinone merupakan turunan dari naftalena melalui penggantian dari dua hydrogen atom oleh dua kelompok keton. Senyawa ini bersifat sitotoksik sebagai insektisida, antibakteri, anti jamur, antivirus, anti inflamasi, dan anti piretik yang digunakan untuk mengobati penyakit ganas dan parasit.

Selain itu Marshall \& Kinghorn (1984) juga menyatakan bahwa salah satu kandungan bahan aktif dari biji cerakin adalah phorbol 13-decanoate; juga phorbol ester lainnya yaitu 4-deoxy-4a-phorboldiester, phorbol monoester dan 4-deoxy-4 $\alpha$-phorbolmonoester Senyawa phorbol ester yang ditemukan paling tinggi konsentrasinya adalah phorbol 12 tiglate 13-decanoate dan terdapat dalam bentuk minyak (Minyak Kroton, MK) dan dikatakan efektif dalam penggunaan sebagai pestisida (Duke, 1983). Sejalan dengan hal tersebut Deshmukh \& Borle (1975) menyatakan bahwa MK mengandung 0,125\% yang bersifat seperti racun nikotin sulfat (insektisida). Kemudian mempunyai sifat lebih efektif dari ekstrak Derris yang merupakan insektisida (List \& Horhammer, 1969-1979) dan bersifat aktif sebagai moluksida terhadap sejenis keong kecil Oncemelania quadrasi (Mashiguchi dkk., 1977) Sediaan biji cerakin dilaporkan aktif terhadap beberapa jenis serangga termasuk kepik Dysdercus koenigii, kutu daun Lipaphis erysimi, lalat rumah Musca domestica, ulat daun bawang Spodoptera exigua dan ulat grayak Spodoptera litura (Grainge \& Ahmad, 1988).

Selain itu berdasarkan penelitian Roufiq (2012) dengan menggunakan GC-MS diperoleh enam senyawa aktif pada biji 
cerakin yang diketahui sebagai insektisida yaitu butacarboxim, 2,3,6-trichlorphenol, dnoc, propamocarb,1,4-naphthoquinone dan piperidine, 1-(1-oxo-3-phenyl-2-propynyl). Empat dari senyawa aktif yang ditemukan tersebut diketahui sebagai bahan pestisida. Maka dapat dikatakan bahwa ekstrak biji cerakin dapat berpotensi sebagai salah satu pestisida alami yang dapat digunakan.

\section{Kesimpulan}

Berdasarkan hasil penelitian maka dapat disimpulkan bahwa ekstrak biji cerakin dapat digunakan sebagai insektisida alami terhadap ulat daun bawang (Spodoptera exigua) dan mampu membunuh larva ulat daun bawang $93,3 \%$ sampai $100 \%$.

\section{Ucapan Terima Kasih}

Penulis mengucapkan terimakasih kepada laboran di Laboratorium FKIP Universitas Tadulako dan semua pihak yang telah banyak membantu penulis dalam melakukan penelitian ini.

\section{Referensi}

Ahmadi, Pranowo, Suherman, \& Hadad. (2011). Ceraken (croton tiglium l) tanaman sumber bahan pestisida nabati, Majalah Semi Populer Tree Tanaman Rempah dan Industry. Retrieved from http://balittri. litbang.pertanian.go.id/index.php/ publikasi/category/11-newletter-januari2011? download=37\%3Ajanuari-2011

Ardiansyah, Wiryanto, \& Mahajoeno. (2002). Toksisitas ekstrak daun mimba (azadirachta indica A. Juss) pada anakan siput murbei (pomacea canaliculata L.). Biosmart, 4(1), 29-34.

Babula, P., Adam, V., Have, L., \& Kizek, R. (2007). Naphthoquinones and their pharmacological properties. Retrieved from http://www.banglajol.info/index.php/JBS/ article/viewFile/2153/1934

Corbet, J. R. K., Wright, A. C., \& Baillie, M. N. (1984). The biochemical mode of action of pesticides. London: Academic Press.

Deshmukh, S. D., \& Borle, M. N. (1975). Studies on the insecticial properties of indigenous products Indian. Journal Entomology, 37(1), 11-18.

Duke, J. A. (1983). Euphorbiaceae. purging croton, physic nut, croton-oil plant handbook of energy crops. Retrieved from http://www. hort.purdue.edu/newcrop/duke_energy/ Croton_tiglium.html.

Grainge, M., \& Ahmad, S. (1988). Handbook of plants with pest control properties. New York: John Wiley \& Sons.

Iswantini, D., Rosman, R., Mangunwidjaja, D., Hadi, U. K., \& Rahminiwat, M. (2007). Bioprospeksi tanaman obat kamandrah (croton tiglium 1.) : Studi agrobiofisik dan pemanfaatannya sebagai larvasida hayati pencegah demam berdarah dengue. Laporan hasil penelitian KKP3T: Institut Pertanian Bogor bekerjasama dengan Badan Penelitian dan Pengembangan Pertanian Jakarta.

Koeman, J. H. (1987). Pengantar umum toksikologi (R. H. Yudono, Trans.). Yogyakarta: UGM Press.

List, P. H., \& Horhammer, L. (1969-1979). Hager's hanbuch de pharmazcutisschen praxis (Vol. 2-6). Berlin: Springer-Velag.

Lu, F. C. (1995). Toksikologi dasar, azas, organ sasaran, dan penilaian resiko (E. Nogroho, Trans. Kedua ed.). Jakarta: PT. Gramedia Pustaka Utama.

Makal, M. V., \& Defly, A. S. (2011). Pemanfaatan ekstrak kasar batang serai untuk pengendalian larva crosidolomia binotalis zell pada tanaman kubis. Eugenia, 17(1), 16-20.

Marshall, G. T., \& Kinghorn, A. D. (1984). Short-chain phorbol ester constituenst of croton oil. Journal American Oil Chemists' Society, 61(7), 1220-1225.

Mashiguchi, J., Yasuraoka, K., Tanaka, H., Santos, A. T., \& Bias, B. L. (1977). Molluscicidal activity of the seed of tuba croton tiglium against oncemelania quadras. Japan Journal Parasitology, 26(5), 37-38.

Prijono, D. (1994). Pedoman praktikum teknik pemanfaatan insektisida botanis. Bogor: IPB.

Rosyidah, A. (2007). Pengaruh ekstrak biji mahoni (swietenia macrophylla king) terhadap mortalitas ulat grayak (spodoptera 
litura f.). Universitas Jember.

Roufiq, N. (2012). Rekayasa proses ekstraksi minyak biji kamandrah (croton tiglium l) dengan pengempaan dan pengembangannya sebagai larvasida nabati pencegah penyakit demam berdarah dengue. (Disertasi), Institut Pertanian Bogor.

Saputera, Djumali, M., Sapta, R., Kardono, L. B. S., \& Dyah, I. P. (2008). Characteristics, efficacy and safety testing of standardized extract of croton tiglium seed from indonesia as laxative material. Pakistan
Journal Biological Science, 11(14), 618-622.

Siregar, N., \& Etti, S. (2005). Kandungan senyawa kimia ekstrak lengkuas (loctuca indica l), toksisitas \& pengaruh subletalnya terhadap mortalitas larva nyamuk Aedes Aegypti L. Skripsi pada Universitas Sumatra Utara, Diterbitkan.

Thamrin, M., Asikin, S., Mukhlis, \& Budiman, A. (2007). Potensi ekstrak flora lahan rawa sebagai pestisida nabati. Laporan Hasil Penelitian Balittra (pp. 35-54): Penelitian Pertanian Lahan Rawa. 